\title{
Experimental Investigation on Strength Parameters of Laterised Concrete after Adding Silica Fume
}

\author{
Lekshmy Rajan ${ }^{1}$, Anup Joy ${ }^{2}$ \\ ${ }^{1}$ PG Scholar, Structural Engineering, Sree Buddha College of Engineering, Pattoor, Alappuzha, Kerala, India \\ ${ }^{2}$ Assistant Professor, Department of Civil Engineering, Sree Buddha College of Engineering, Pattoor, Alappuzha, Kerala, India
}

\begin{abstract}
Cement, sand and aggregates are the basic needs for any construction industry. Sand is a prime material used for preparation of mortar and concrete and which plays a major role in mix design. Now a day's erosion of rivers and considering environmental issues, there is a scarcity of river sand. The non-availability or shortage of river sand will affect the construction industry. Hence there is a need to find the new alternative material to replace the river sand. M-Sand is one of the major alterntive to river sand. But it's over exploitation causes serious environmental issues. Many researchers are finding different materials to replace fine aggregate and one of the major materials is locally available soil. Laterite soil is one of the easily available local soils and using different proportion of this available soil along with $M$-sand the required concrete mix can be obtained. This paper presents a review on the study of effect of silica fume on laterised concrete (concrete in which the fine aggregate is replaced with laterite soil). Initially the optimum percentage of silica fume is determining, with this optimum percentage of silica fume, replacement of fine aggregate with locally available laterite soil with different percentages $(10 \%, 20 \%, 30 \%$ \& $40 \%)$ is done. Tests on workability, compressive strength, flexural resistance, split tensile strength and modulus of elasticity were conducted on specimens. The result is then compared with that of laterised concrete and control concrete. Silica fume improves the bonding as well as compressive strength of concrete. Properties of laterite soil is as good as the regular river sand and M-Sand.
\end{abstract}

Keywords: Silica fume, Local available laterite soil, Alternative material, Compressive Strength

\section{Introduction}

Concrete is a widely used construction material for various types of structures due to its structural stability and strength. The Ordinary Portland Cement (OPC) is one of the main ingredients used for the production of concrete and has no alternative in the civil construction industry. Unfortunately, production of cement involves emission of large amounts of carbon-dioxide gas into the atmosphere, a major contributor for green house effect and the global warming, hence it is inevitable either to search for another material or partly replace it by some other material. Substantial energy and cost savings can result when industrial by products are used as a partial replacement of cement. Addition of silica fume to concrete has many advantages like high strength, durability and reduction in cement production. When pozzolanic materials are incorporated to concrete, the silica present in these materials react with the calcium hydroxide released during the hydration of cement and forms additional calcium silicate hydrate $(\mathrm{C}-\mathrm{S}-\mathrm{H})$, which improve durability and the mechanical properties of concrete.

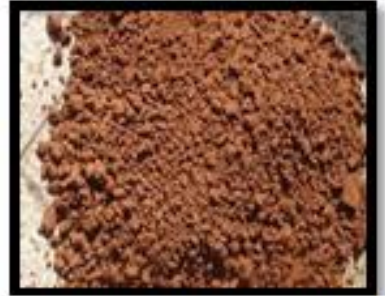

Figure 1[a]: Laterite

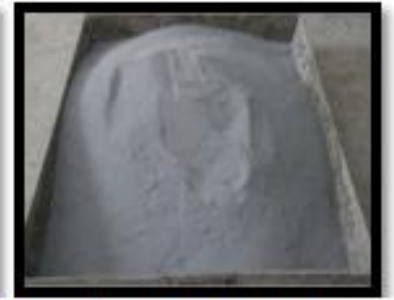

Figure 1[b]: Silica fume
A view from past history of the construction industry, river sand has been used as one of the major components of the building materials due to the ready availability and its wellgraded nature with the sand grains of different sizes well distributed. River sand is mainly used for all kinds of civil engineering constructions. The excessive excavation of river sand is becoming a serious environmental issue. Intensive river sand mining results in the failure of river banks, lowering of river beds, damages to the bridge foundations and other structures situated closer to the river. Hence it is necessary to explore possible alternatives to minimize the use of river sand. A number of attempts have been made to replace the river sand with other materials which are waste in the environment and to utilize those materials which are disposed without being used. M-Sand is one of the major alternatives to river sand. But it's over exploitation causes serious environmental issues. Laterite soil is one of the easily available local soils and using different proportion of this available soil along with $\mathrm{M}$-sand the required concrete mix can be obtained.

In this project the optimum percentages of silica fume and laterite soil that can be used for replacing cement and fine aggregate respectively are finding out. The properties of concrete in fresh and hardened states are studied. An experimental program was carried out to explore its effects on workability, compressive, flexural, split tensile strength and modulus of elasticity of concrete. The focus of a good national development is to look inwards with intent to mobilize all natural resources for economic purposes.

\section{Literature Review}

[1] J. Santhiyaa Jenifer \& S. Ramasundarm (2015)

Studied the physical properties of laterite namely specific gravity, particle size distribution and density. An attempt was made to use of laterite as a fine aggregate in concrete. The quantity of laterite varies from $0 \%$ to $100 \%$ at interval of $25 \%$ in this study. The 1:1.5:3 mix of concrete is used for determining the mechanical strength and durability 


\section{International Journal of Science and Research (IJSR) \\ ISSN (Online): 2319-7064}

Index Copernicus Value (2013): 6.14 | Impact Factor (2015): 6.391

characteristics. The density of laterite mixed concrete increases when percentage of laterite increases. The results of laterite sand mixed concrete are compared with conventional concrete. At 50 percentage replacement of sand by laterite sand produces high compressive strength. The tensile and flexural strength increases when the percentage of laterite sand increases.

[2] Biju Mathew, Benny Joseph \& C Freeda Christy

The natural M-Sand was replaced with laterite at the rate of $10 \%, 20 \%$ and $30 \%$ by weight for design mix of M25 controlled concrete. A total of 36 specimens prepared to determine the cube compressive strength, and flexural strength. From the studies, addition of laterite reduces workability in concrete. Compressive strength decrees with increases in $\%$ of laterite replacement with sand. The flexural strength has only slight variation with controlled concrete. Laterite of $20 \%$ by weight of sand content has shown the best results, thus indicating possibility of using laterite as a partial replacement.

\section{[3] Prof. Vishal S. \& Pranita S.Bhandari (2013)}

Here an attempt is made to partially replace Portland cement by silica fume. The main objective of this research work was to determine the optimum replacement percentages of silica fume. To fulfill the objective various properties of concrete using silica fume have been evaluated. Further to determine the optimum replacement percentage comparison between the regular concrete and concrete containing silica fume is done .It has been seen that when cement is replaced by silica fume compressive strength increases up to certain percentage $(10 \%$ replacement of cement by silica fume).But higher replacement of cement by silica fume gives lower strength

\section{[4] Debabrata Pradhan \& D. Dutta (2013)}

The main objective of this paper has been made to investigate the different mechanical properties like compressive strength, compacting factor, slump of concrete incorporating silica fume. The experiments were carried out by replacing cement with different percentages of silica fume at a single constant water-cementitious materials ratio keeping other mix design variables constant. The silica fume was replaced by $0 \%, 5 \%, 10 \%, 15 \%$ and $20 \%$ for watercementitious materials $(\mathrm{w} / \mathrm{cm})$ ratio for 0.40 . For all mixes compressive strengths were determined at 24 hours, 7 and 28 days for $100 \mathrm{~mm}$ and $150 \mathrm{~mm}$ cubes. Other properties like compacting factor and slump were also determined for five mixes of concrete. The optimum percentage of replacement of silica fume is obtained was $10 \%$

\section{Objective \& Scope of the Work}

The scope of this study is more about the determination of the strength of concrete with replacement of M-Sand by laterite and find out the effect of silica fume on concrete where fine aggregate is replaces with laterite soil. This study will therefore introduce new alternatives for fine aggregate.

\section{Tests of Materials}

Table 1: Material Testing Results

\begin{tabular}{|c|c|c|}
\hline Materials & Test & $\begin{array}{c}\text { Results } \\
\text { Obtained }\end{array}$ \\
\hline Ramco cement (OPC 43 grade) & Specific Gravity & 3.13 \\
\hline Fine Aggregates [M-Sand] & Specific Gravity & 2.61 \\
\hline Laterite soil & Specific Gravity & 2.56 \\
\hline \multirow{2}{*}{ Coarse Aggregates } & Specific Gravity & 2.77 \\
\cline { 2 - 3 } & Water absorption & $0.60 \%$ \\
\hline M30 concrete & Workability & $100 \mathrm{~mm}$ \\
\hline
\end{tabular}

\subsection{Silica fume \{grade 920D $\}$}

Silica fume used was confirming to ASTM- C (1240-2000) and was named micro silica $920 \mathrm{D}$.

Table 2: Silica Fume Chemical \& Physical Analysis Report

\begin{tabular}{|c|c|c|}
\hline Sl.no & Chemical Analysis & Results \\
\hline 1 & $\mathrm{SiO}_{2}$ & 92 \\
\hline 2 & Moisture content & $<2$ \\
\hline 3 & Loss on ignition & 3.85 \\
\hline 4 & Alkalies as $\mathrm{Na}_{2} \mathrm{O}$ & 0.8 \\
\hline \multirow[t]{2}{*}{5} & $\mathrm{pH}$ value & 8 \\
\hline & Physical Analysis & \\
\hline 1 & Specific surface, $\mathrm{m}^{2} / \mathrm{g}$ & 20 \\
\hline 2 & $\begin{array}{c}\text { Maximum oversize \% retained on IS } 45 \\
\text { micron Sieve }\end{array}$ & 8 \\
\hline 3 & $\begin{array}{c}\text { Compressive strength at } 7 \text { days as percentage } \\
\text { of control sample }\left[\mathrm{N} / \mathrm{mm}^{2}\right]\end{array}$ & 87.26 \\
\hline
\end{tabular}

\subsection{Super Plasticizer}

In this investigation super plasticizer- CONPLAST-SP 430 in the form of sulphonated Naphthalene polymers complies with IS: 9103-1999 and ASTM 494 type F was used to improve the workability of concrete. Conplast SP 430 has been specially formulated to give high water reductions up to $25 \%$ without loss of workability or to produce high quality concrete of reduced permeability. The properties of super plasticizer are shown in Table 3.

Table 3: Properties of super plasticizer

\begin{tabular}{|c|c|c|}
\hline Sl. No. & Physical properties & Result \\
\hline 1 & Specific Gravity & 1.224 \\
\hline 2 & Chloride Content & NIL \\
\hline 3 & Air Entrainment & $11.73 \mathrm{Lb} / \mathrm{Ft}^{3}$ \\
\hline
\end{tabular}

\section{Experimental Investigation}

\subsection{Overall Scheme of Experimental Investigation}

In this study the parameters considered are workability, cube compressive strength, flexural strength and split tensile strength. The mix proportion for M30 concrete designed as per provisions in IS Codes were considered for this investigation. To study the effect of silica fume on laterised concrete initially the cement is replaced with silica fume and its optimum percentage replacement is determined. For that silica fume of four different proportions viz. 5\%,10\%,15\% and $20 \%$ of weight of cement were used in concrete. 24 


\section{International Journal of Science and Research (IJSR) \\ ISSN (Online): 2319-7064}

Index Copernicus Value (2013): 6.14 | Impact Factor (2015): 6.391

cubes $(150 \mathrm{~mm}), 12$ beams and 12 cylinders were tested in this study.

Then the optimum percentage of cementatious material is fixed and laterite of $10 \%, 20 \%, 30 \%$ and $40 \%$ of weight of fine aggregate were used to make the corresponding concrete. 24 cubes $(150 \mathrm{~mm}), 12$ beams and 12 cylinders were tested in this investigation.

\subsection{Materials Used}

Ordinary Portland cement 43 grades, locally available good quality M-Sand of specific gravity 2.61 passing through $4.75 \mathrm{~mm}$ IS sieve conforming to zone II , coarse aggregate of specific gravity 2.77 , laterite of specific gravity 2.56 and fineness modulus 2.73, Silica fume \{grade 920D\} and Potable water were used for making the various concrete mixes considered in this study. Silica fume used was confirming to ASTM- C (1240-2000).

\subsection{Mix Design}

M30 concrete mix was designed as per IS 10262-2009. The mix obtained as per IS code design is of proportion 1: 1.579: 2.5: 0.45 . The quantity required for $1 \mathrm{~m}^{3}$ concrete as given in Table 4.1. For all replacement level, the same mix ratio for normal concrete followed. In this investigation, the $\%$ of replacement of laterite made without effecting $\mathrm{W} / \mathrm{C}$ ratio and mix proportion.

\subsection{Preparation of Test Specimen}

Slump test and compaction factor tests was conducted for each mix to assess the workability. Concrete cubes $(150 \mathrm{~mm})$ for determining compressive strength, beams (100 mmx $100 \mathrm{~mm} \times 500 \mathrm{~mm}$ ) for determining flexural strength and cylinders for split tensile strength are casted. Concrete cube specimens were tested at 7 and 28 days to obtain the compressive strength of concrete. Cylindrical and beam specimens were tested at 28 day to obtain the split tensile strength, modulus of elasticity and flexural strength of concrete.

\section{Experimental Results and discussion}

\section{A. Optimization of silica fume}

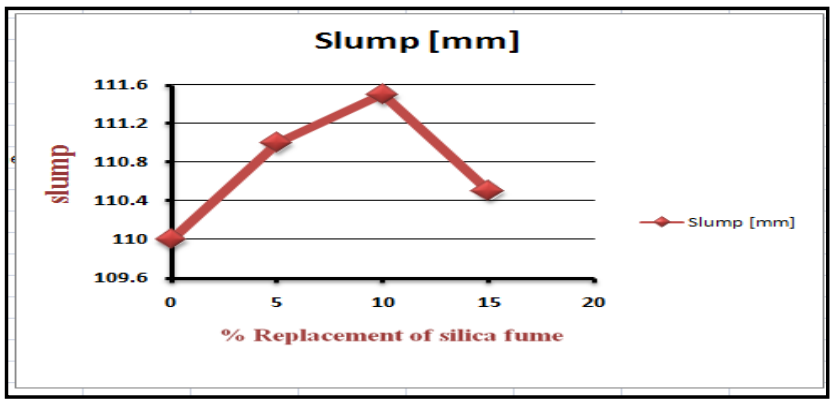

Figure 2: Slump value of M30 grade concrete

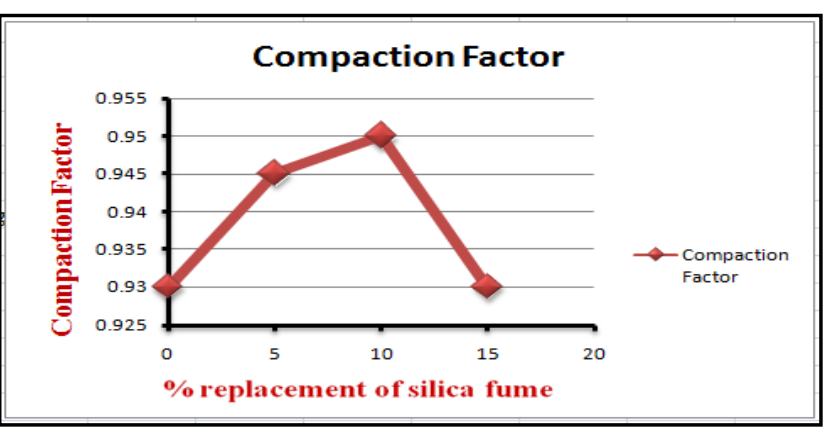

Figure 3: Compaction factor of M30 grade concrete

Table 4: Compressive strength of the specimens

\begin{tabular}{|c|c|c|c|}
\hline $\begin{array}{c}\text { S. } \\
\text { No }\end{array}$ & $\begin{array}{c}\% \\
\text { Replacement of } \\
\text { silica fume }\end{array}$ & $\begin{array}{c}7 \text { days } \\
\text { Compressive } \\
\text { strength }\left(\mathrm{N} / \mathrm{mm}^{2}\right)\end{array}$ & $\begin{array}{c}\text { 28 days compressive } \\
\text { strength }\left(\mathrm{N} / \mathrm{mm}^{2}\right)\end{array}$ \\
\hline 1 & 0 & 25.21 & 38.20 \\
\hline 2 & 5 & 26.14 & 39.63 \\
\hline 3 & 10 & 28.89 & 40.52 \\
\hline 4 & 15 & 27.79 & 39.924 \\
\hline
\end{tabular}

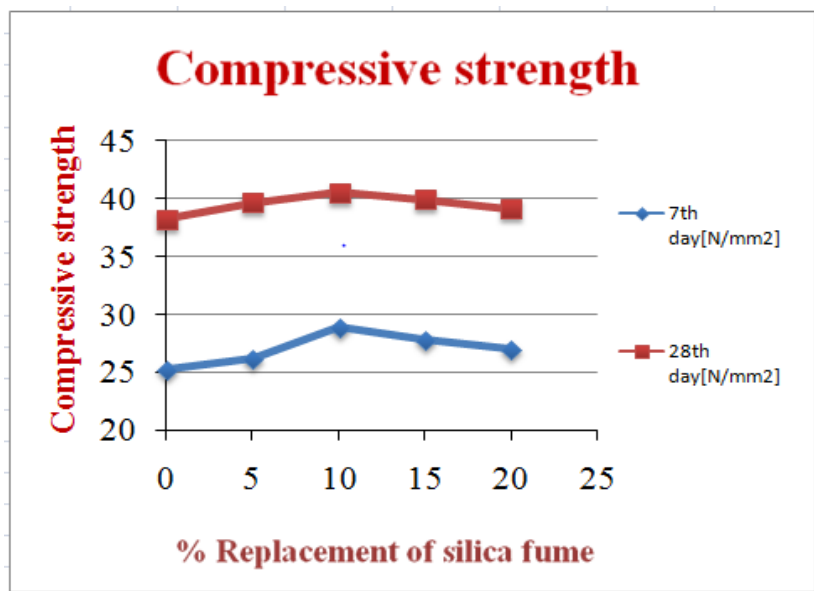

Figure 4: Compression value of concrete

Table 5: Split tensile strength of the specimens

\begin{tabular}{|c|c|c|}
\hline Sl.No & $\begin{array}{c}\text { \% Replacement of silica } \\
\text { fume }\end{array}$ & $\begin{array}{c}28 \text { days Split tensile strength } \\
\left(\mathrm{N} / \mathrm{mm}^{2}\right)\end{array}$ \\
\hline 1 & 0 & 3.42 \\
\hline 2 & 5 & 3.54 \\
\hline 3 & 10 & 3.67 \\
\hline 4 & 15 & 3.62 \\
\hline
\end{tabular}

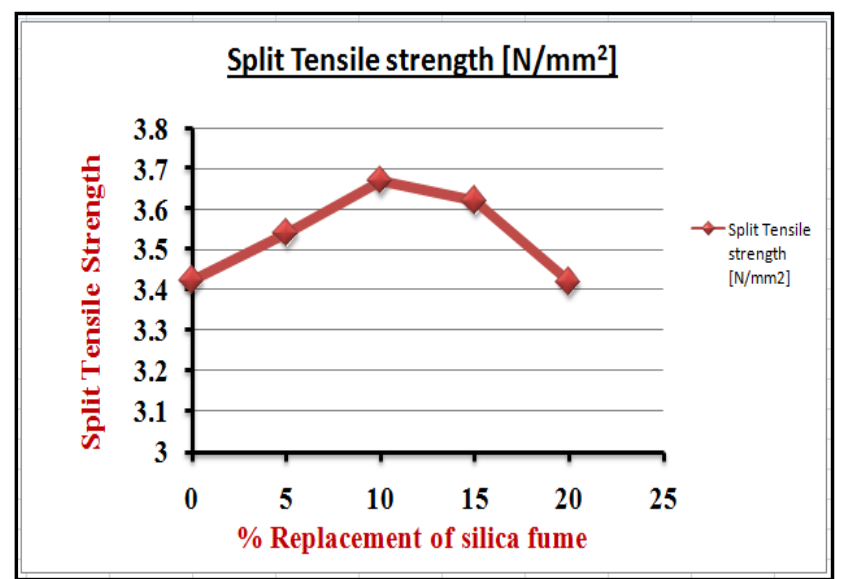

Figure 5: Tensile strength of the concrete

Volume 5 Issue 6, June 2016 www.ijsr.net 


\section{International Journal of Science and Research (IJSR) \\ ISSN (Online): 2319-7064}

Index Copernicus Value (2013): 6.14 | Impact Factor (2015): 6.391

Table 6: Flexural strength of the specimens

\begin{tabular}{|c|c|c|}
\hline Sl.No & $\begin{array}{c}\text { \% Replacement } \\
\text { of silica fume }\end{array}$ & $\begin{array}{c}\text { 28days Flexural } \\
\text { strength }\left(\mathrm{N} / \mathrm{mm}^{2}\right)\end{array}$ \\
\hline 1 & 0 & 4 \\
\hline 2 & 5 & 4.24 \\
\hline 3 & 10 & 5.04 \\
\hline 4 & 15 & 4.08 \\
\hline
\end{tabular}

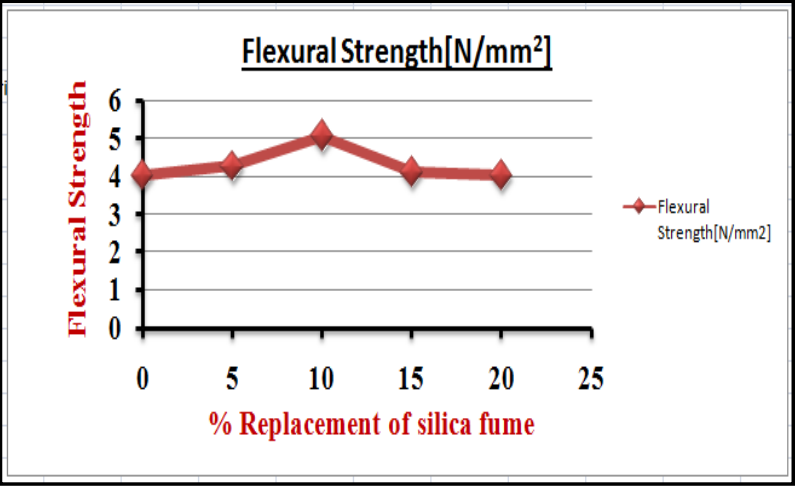

Figure 6: Flexural strength of the concrete

Table 7: Modulus of elasticity of the specimens

\begin{tabular}{|c|c|c|}
\hline Sl.No & $\begin{array}{c}\text { \% Replacement of } \\
\text { silica fume }\end{array}$ & Young's Modulus ( $\mathrm{GPa}$ ) \\
\hline 1 & 0 & 38.97 \\
\hline 2 & 5 & 40.476 \\
\hline 3 & 10 & 41.83 \\
\hline 4 & 15 & 39.59 \\
\hline
\end{tabular}

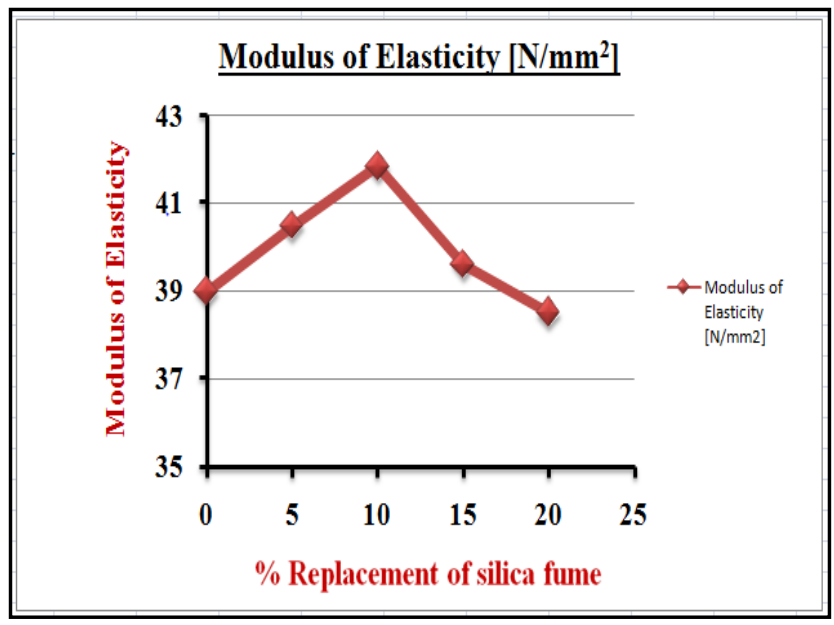

Figure 7: Modulus of elasticity

Found that the optimum level for the replacement of the silica fume was $10 \%$.

\section{B. Optimization of laterite in optimum replacement of} silica fume

In this section laterite soil of different percentage added with optimum replacement of silica fume for the fine aggregate in concrete.

Table 8: Compressive strength of the specimens

\begin{tabular}{|c|c|c|c|}
\hline $\begin{array}{c}\text { S. } \\
\text { No }\end{array}$ & $\begin{array}{c}\% \\
\text { of laterite }\end{array}$ & $\begin{array}{c}7 \text { days Compressive } \\
\text { strength }\left(\mathrm{N} / \mathrm{mm}^{2}\right)\end{array}$ & $\begin{array}{c}28 \text { days compressive } \\
\text { strength }\left(\mathrm{N} / \mathrm{mm}^{2}\right)\end{array}$ \\
\hline 1 & 0 & 25.2 & 38.2 \\
\hline 2 & 10 & 29.704 & 41.48 \\
\hline 3 & 20 & 31.53 & 43.2 \\
\hline 4 & 30 & 30.89 & 42.57 \\
\hline
\end{tabular}

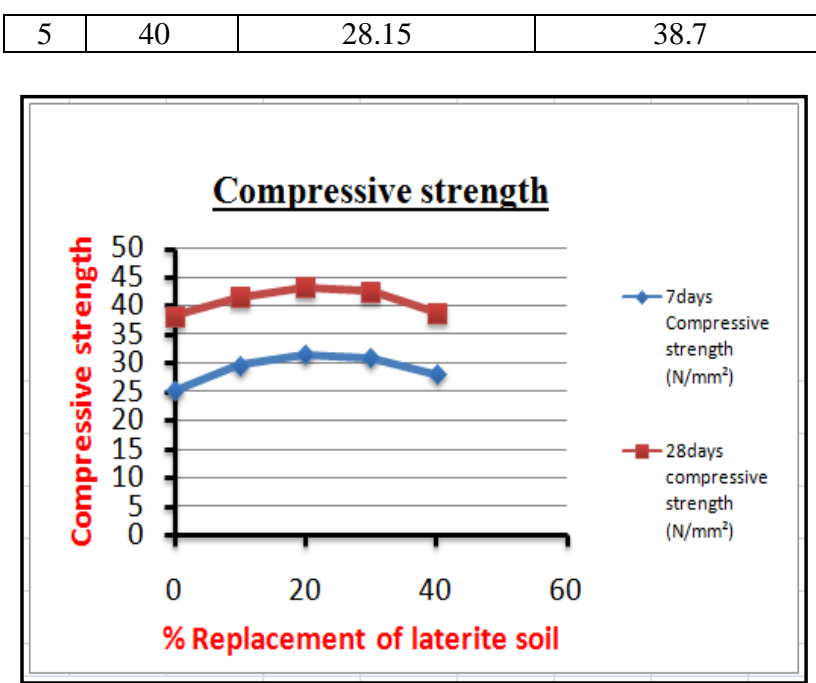

Figure 8: Compression value of concrete

Table 9: Split tensile strength of the specimens

\begin{tabular}{|c|c|c|}
\hline Sl.No & $\begin{array}{c}\% \\
\text { oflaterite }\end{array}$ & $\begin{array}{c}\text { 28days Split tensile strength } \\
\left(\mathrm{N} / \mathrm{mm}^{2}\right)\end{array}$ \\
\hline 1 & 0 & 3.42 \\
\hline 2 & 10 & 4.10 \\
\hline 3 & 20 & 4.5 \\
\hline 4 & 30 & 4 \\
\hline 5 & 40 & 3.85 \\
\hline
\end{tabular}

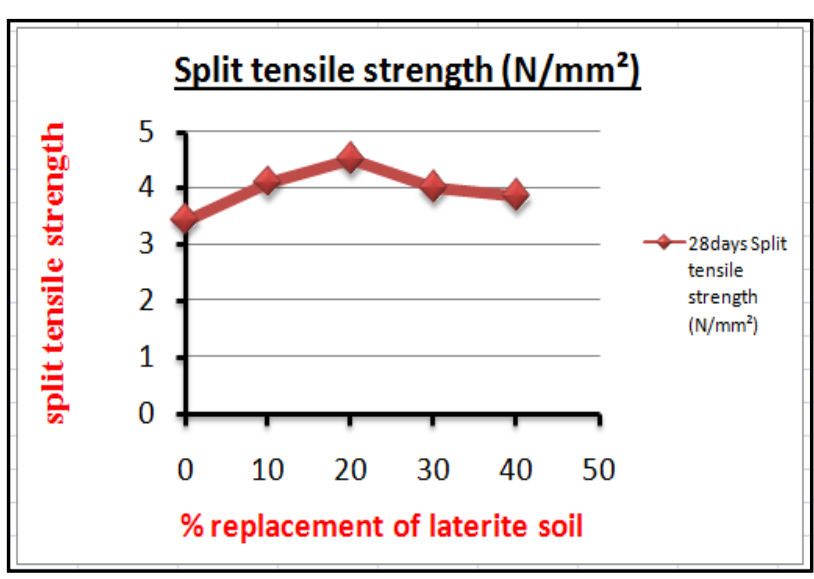

Figure 9: Split tensile strength of the specimens

Table 10: Flexural strength of the specimens

\begin{tabular}{|c|c|c|}
\hline Sl.No & \% of laterite & 28days Flexural strength $\left(\mathrm{N} / \mathrm{mm}^{2}\right)$ \\
\hline 1 & 0 & 4 \\
\hline 2 & 10 & 4.4 \\
\hline 3 & 20 & 5.2 \\
\hline 4 & 30 & 4.3 \\
\hline 5 & 40 & 4 \\
\hline
\end{tabular}

Volume 5 Issue 6, June 2016 www.ijsr.net

Licensed Under Creative Commons Attribution CC BY 


\section{International Journal of Science and Research (IJSR) \\ ISSN (Online): 2319-7064}

Index Copernicus Value (2013): 6.14 | Impact Factor (2015): 6.391

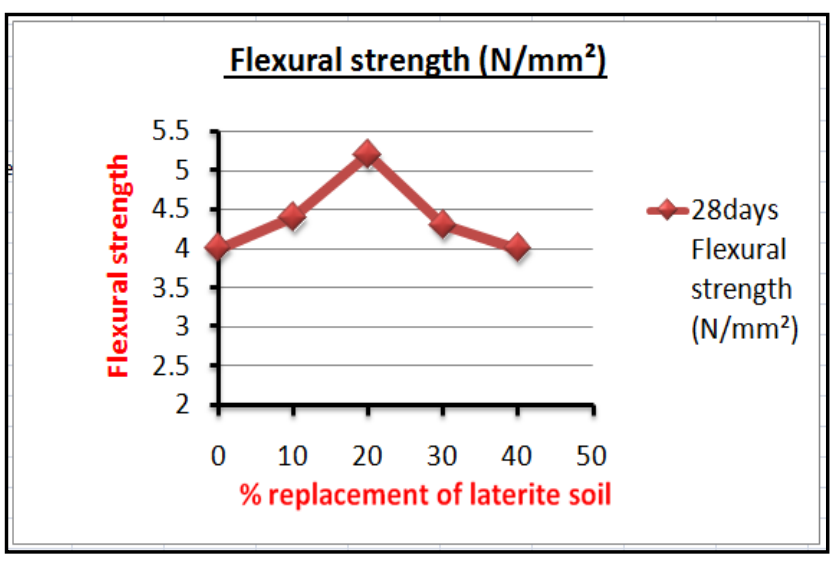

Figure 10: Flexural strength of the specimens

Table 11: Modulus of elasticity of the specimens

\begin{tabular}{|c|c|c|}
\hline Sl.No & \% of laterite & Young's Modulus $(\mathrm{GPa})$ \\
\hline 1 & 0 & 28.6 \\
\hline 2 & 10 & 41.98 \\
\hline 3 & 20 & 42.85 \\
\hline 4 & 30 & 40.1 \\
\hline 5 & 40 & 39.89 \\
\hline
\end{tabular}

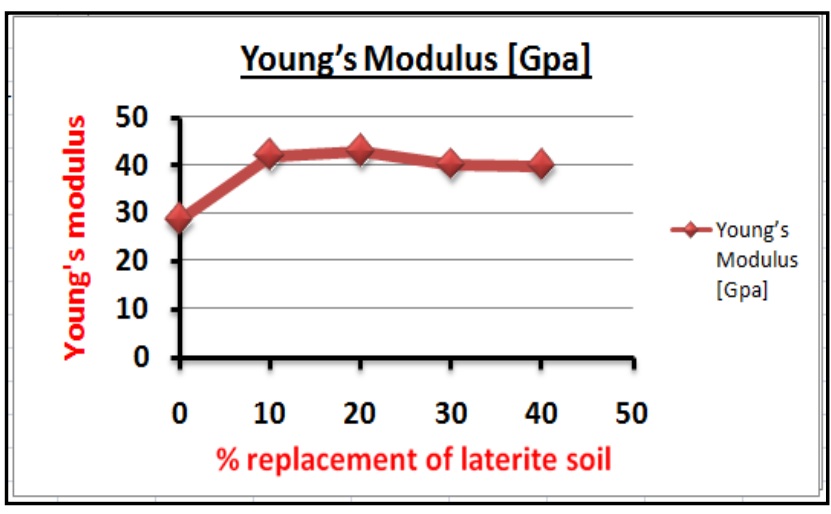

Figure 11: Modulus of elasticity of the specimens

From this experimental study it is revealed that by using $20 \%$ of laterite soil with $10 \%$ silica fume in concrete gives maximum strength.

\section{Conclusions}

Based on the present study the following conclusions were derived: The optimum 7 and 28-day compressive strength and flexural strength have been obtained at $10 \%$ silica fume replacement level. Increase in split tensile strength beyond $10 \%$ silica fume replacement is almost insignificant. Compressive strength of $10 \%$ silica fume and $20 \%$ laterite added concrete has found to be $14 \%$ increase in strength, when compared to that of Conventional concrete. Strength enhancement in split tensile strength is $31.6 \%$, flexural strength is $30 \%$ and modulus of elasticity is $15 \%$ compared to that of Conventional concrete. This replacement $f$ cement and fine aggregate by silica fume and locally available laterite soil can reduce the construction cost and also it reduces the over exploitation of natural resources.

\section{References}

[1] Adams Joe, A. Maria Rajesh, P. Brightson and M. Prem Anand, (2014), "Experimental investigation on the effect of M-Sand in High Performance Concrete", American Journal of Engineering Research (AJER), Vol. 2.

[2] A. Emmanuel, A. Allan, (2014), "Suitability of Laterite fines as a partial replacement for sand in the production of Sandcrete bricks", International Journal of Emerging Technology and Advanced Engineering, Vol. 4.

[3] Adams Joe, A. Maria Rajesh, P. Brightson and M. Prem Anand, (2014), "Experimental investigation on the effect of M-Sand in High Performance Concrete", American Journal of Engineering Research (AJER), Vol. 2.

[4] Bayasi, Zing, Zhou, Jing, (1993) "Properties of Silica Fume Concrete and Mortar", ACI Materials Journal 90 (4) 349 - 356.

[5] Bhanja Santanu, and Sengupta Bratish, (September,2003). “Optimum Silica Fume Content and Its Mode of Action on Concrete", ACI Materials Journal, V (100), No. 5, pp. 407-412.

[6] Bhikshma, K.Nitturkar and Y.Venkatesham, "Investigations on mechanical properties of high strength silica fume concrete." Asian journal of civil engineering (building and housing) vol. 10, no. 3 (2009) pp.335-346

[7] Khedr, S. A., Abou - Zeid, M. N., (1994) "Characteristics of Silica-Fume Concrete", Journal of Materials in Civil Engineering, ASCE 6 (3) 357 - 375.

[8] Satish and A.M.N. Kashyap, (2014), "Replacement of Fine Aggregate with Local available Soil", International Journal of Engineering Research and Development, Vol. 10.

[9] T.S.Thandavamoorthy, (2014), "Feasibility of making concrete from Local soil instead of River sand", ICI Journal, Vol. 15

[10] S. Elavenil, B. Vijaya, (2013), "Manufactured Sand, a solution and an alternative to River Sand and in concrete manufacturing", Journal of Engineering, Computers \& Applied Sciences (JEC\&AS), Volume 2.

\section{Volume 5 Issue 6, June 2016 www.ijsr.net}

